Original article

\title{
E-Pharmacophore Mapping Combined with Virtual Screening and Molecular Docking to Identify Potent and Selective Inhibitors of P90 Ribosomal S6 Kinase (RSK)
}

\author{
Abdulilah ECE \\ Biruni University, Faculty of Pharmacy, Department of Pharmaceutical Chemistry, Istanbul, \\ TURKEY
}

\begin{abstract}
The p90 ribosomal S6 kinases (RSK) are a family of serine/threonine protein kinases and are shown to be involved in cancer cell proliferation. The lack of highly selective inhibitors and also the lack of structural information regarding the mechanism of those inhibitors restricts the progress in this field. It has also been reported that without a proper crystal structure of RSK, the protein-inhibitor interactions in silico studies had been erroneously concluded. The first e-pharmacophore model for RSK2 has been generated in this study using recently resolved high resolution crystal structure of RSK2 in complex with LJH685 that is amongst the most potent and selective RSK inhibitors to date. 12 compounds have been suggested as promising potent and selective RSK inhibitors after the combination of virtual screening of a large database (ca. 7 million compounds with more than 144 million conformations), followed by a series of molecular docking work flow and visual inspection of all hits for critical binding modes. Amongst those hits, 5777208 and 5919607 have been found to have remarkable docking score and binding interactions.
\end{abstract}

Key words: RSK, E-pharmacophore, Cancer, Virtualsscreening, Docking.

\section{E-Farmakofor Haritalanması, Sanal Tarama ve Moleküler Kenetlenmenin Birleştirilmesi ile Etkili ve Seçici P90 Ribosomal S6 Kinaz (RSK) İnhibitörlerinin Belirlenmesi}

p90 Ribozomal kinazlar serin/treonin protein kinaz ailesindendir ve kanser hücrelerinin çoğalmasında rol aldıkları saptanmıştır. Yüksek seçiciliğe sahip inhibiötlerin ve aynı zamanda bu inhibitörlerin mekanizmalarına ait yapısal bilgilerin eksikliği, bu alanda ilerlemeyi kısıtlamaktadır. Uygun bir RSK kristal yapısı olmadan yapılan in siliko protein-inhibitör çalışmalarında da yanlış sonuçlara varıldığı söylenmiştir. Bu çalışmada, yeni çözümlenen, en etkili ve seçici RSK inhibitörlerinden LJH685 ile kompleks halinde olan, yüksek çözünürlükteki RSK2 kristal yapısı kullanılarak, RSK2'ye ait ilk efarmakofor modeli oluşturulmuştur. Büyük veri tabanlarının (144 milyondan fazla konformasyona sahip yaklaşık 7 milyon bileşik) sanal taraması, ardından bir dizi moleküler kenetleme çalışması ve kritik bağlanma modlarının görsel olarak incelenmesi çalışmalarının birleştirilmesi ile 12 bileşik umut vaat eden etkili ve seçici inhibitörler olarak önerilmiştir. Bu bileşikler arasından 5777208 ve 5919607'nin kayda değer kenetlenme skorlarının ve bağlanma etkileşimlerinin olduğu bulunmuştur.

Anahtar kelimeler: RSK, E-farmakofor, Kanser, Sanal tarama, Kenetlenme.

Correspondence: E-mail: aece@biruni.edu.tr/abdulilahece@yahoo.com; Tel: 02124164646

\section{INTRODUCTION}

Protein phosphorylation is a key mechanism of regulating protein function in eukaryotic cells. Protein kinases catalysis the phosphorylation of either Ser/Thr or Tyr residues on target proteins (1). Hence, they have been selected as drug target, particularly in cancer therapy (2). Several drugs targeting protein kinases have been approved by the FDA and many other small molecule inhibitors are known to be in clinical 
development $(3,4)$. The p90 ribosomal S6 kinase (RSK) family of serine/threonine kinases which has four isoforms (RSK1-4) (2) is widely expressed in a variety of cancers and described to phosphorylate a number of proteins linked to the regulation of cell survival and proliferation (5).

The lack of highly selective inhibitors and also the lack of structural information regarding the mechanism of those inhibitors have been the reason for the limited full understanding of RSK kinase family $(5,6)$. Discovering novel and specific inhibitors of RSK, especially through computational methods has also been impeded by the lack of insufficient crystal structural information. It has been reported that without a proper crystal structure of RSK, the in silico studies regarding protein-inhibitor interactions had been erroneously concluded $(2,6)$. On the other hand, the identified RSK2 inhibitors are not enough for building a reliable ligand based pharmacophore model.

Recently Aronchik et. al., has synthesized two inhibitors, LJH685 and LJI308, that have been reported to be the most selective and potent RSK inhibitors known to date (7). The high resolution crystal structure of RSK2 in complex with LJH685 has also been solved in the same study.

This study aims to generate the first epharmacophore model for RSK2 and use it as a query for screening huge small molecule commercial compound collection ( $\mathrm{CoCoCo}$ ) database that consists of ca. 7 million compounds with over 144 million conformations from different vendors (8). Epharmacophore is a novel approach that has the advantages of both ligand and structurebased pharmacophore generation approaches. The obtained hits from virtual screening was further refined using docking studies and potential lead compounds have been suggested based on binding interactions with RSK2 active site.

\section{EXPERIMENTAL}

\section{Protein preparation}

Protein crystal structure of RSK2 in complex with the LJH685 ligand having a resolution of $2.39 \AA$ was downloaded from protein databank (PDB ID: 4NUS) and prepared using the Protein Preparation Wizard (PrepWizard) in Maestro of Schrödinger software package (9). This wizard makes it possible to improve enrichment in virtual screening by overcoming problems related with initial protein structures (10). Any necessary hydrogen atoms were added and all water molecules were removed in the PrepWizard. The protein structure was refined by correcting the missing side chain atoms, assigning the bond orders and adding the polar hydrogen atoms to the receptors. After the optimization step, the refined structure was further minimized using OPLS3 force field.

\section{Molecular docking}

The docking calculations were performed using the Glide XP (extra precision) module of the Maestro (11). A grid that represents the active site of the target has to be generated prior to the molecular docking. The substrate location in the RSK2 protein structure was used to choose the center and size of the receptor grid using Schrödinger's Glide. The default setting for the grid size was changed to include all active site residues to allow ligands having $\leq 20 \AA$ size to be docked.

\section{E-pharmacophore generation}

The energy-optimized pharmacophore (Epharmacophore) feature maps the energetic terms obtained from docking calculations to the atom centers through the Glide XP scoring function. Pharmacophore sites with a default set of six chemical characteristics namely, hydrogen bond donor (D), hydrogen bond acceptor (A), hydrophobic site $(\mathrm{H})$, aromatic ring $(\mathrm{R})$, positive ionizable group $(\mathrm{P})$ and the negative ionizable group $(\mathrm{N})$ were generated using the Phase module (12) for the best scoring pose in the RSK2-LJH685 complex obtained from the Glide XP docking calculations. The sum of the Glide XP energetic terms of each atom was assigned to the corresponding pharmacophore features. This mapping of the energy terms to the pharmacophores enables to select the pharmacophore sites which contribute most to the ligand-receptor interaction. 
Virtual screening workflow

The Virtual Screening Workflow script in Schrödinger package was used. Two choices for prefiltering ligands were used: prefiltering using Lipinski's Rule of 5 and removing ligands with reactive functional groups. Ligands that do not meet the specified criteria were removed from the ligand list for docking. Then all the ligands were submitted to three step docking procedures: in the first step, the ligands were docked with Glide HTVS and then, $10 \%$ of best compounds were docked with Glide SP. In this step, also 10\% of best compounds, but now keeping only good scoring states, were passed to the final step. Ultimately, the successful ligands were docked using Glide XP and 10\% of best compounds retaining only best scoring states were given as output.
RSK2 kinase also possesses a threonine residue at the gatekeeper site. The native ligand, LJH685, which has been reported to be one of the most selective and potent RSK inhibitors known to date, makes a hydrogen bond with the Leu150 residue of RSK2 active site. Although the Phe212 in active region of RSK2 flips out of the Asp-Phe-Gly (DFG) motif, LJH685 is restricted by the Asp211 of the DFG from access to the hydrophobic pocket. But the difluorophenyl ring of $\mathrm{LJH68}$ is binding to the gatekeeper area in a propeller-shaped arrangement which has been reported to be the reason for its significantly improved selectivity profile (7).

In the current study, molecular docking study was performed as a first step. The main objective of the molecular docking is to identify the energetically favorable binding

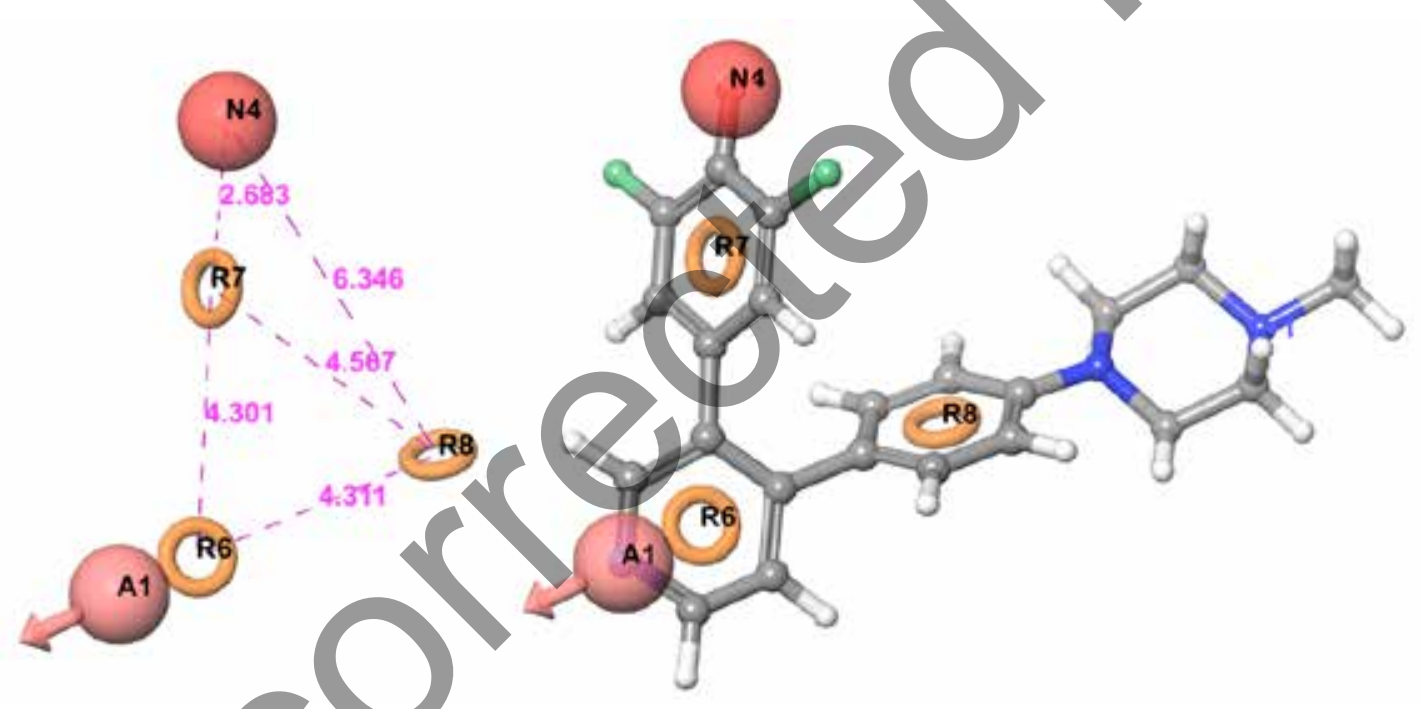

Figure 1. E-pharmacophore model for RSK2 (left) and the model mapped onto LJH685 (A: hydrogen bond acceptor; R: aromatic ring; N: negative ionizable group).

\section{RESULTS AND DISCUSSION}

Selectivity of the kinase inhibitors have been related to some key determinants and one of which is known as "gatekeeper" (13). This generates a hydrophobic site near the ATP binding site (14). A threonine residue exists in a few number of kinase families including RSK2. This compact gate keeper allows bulky aromatic substituents to enter a deep hydrophobic pocket whereas larger gatekeepers (e.g. methionine or phenylalanine) restrict access to this pocket (13). modes of ligands into the target's binding site. This can shed a light on the nature of the binding site and the key ligand-protein interactions (15). The cocrystal native ligand (LJH685) was first docked into the RSK2 protein structure using XP method. The superposition of the docked ligand and native ligand had an RMSD value of 0.68 .

The pharmacophore sites were defined from XP descriptor information after XP docking of the native ligand. E-pharmacophore model was generated selecting 5 pharmacophore sites based on their energy values (Figure 1). 
Table 1. Docking scores of the native ligand and selected hit compounds.

\begin{tabular}{lllll}
\hline Ligand & Docking Score (kcal/mol ) & CoCoCo_ID & VENDOR & Fitness \\
\hline LJH68 (Native Ligand) & -12.282 & - & - & \\
\hline 5777208 & -13.183 & 5777208 & NCI & 1.654556 \\
\hline 1356444 & -12.714 & 1356444 & CBN & 1.553880 \\
\hline 5919607 & -12.426 & 5919607 & PRN & 2.114975 \\
\hline 1906060 & -12.049 & 1906060 & CHD & 1.495216 \\
\hline 2231818 & -11.763 & 2231818 & CHD, PRN & 1.765809 \\
\hline 6739988 & -11.693 & 6739988 & PRN & 2.137922 \\
\hline 810148 & -11.680 & 810148 & CBE, PRN & 2.073499 \\
\hline 5923852 & -11.654 & 5923852 & PRN & 2.100553 \\
\hline 1963198 & -11.420 & 1963198 & CHD & 1.544532 \\
\hline 4501898 & -11.018 & 4501898 & ENM & 1.548856 \\
\hline 1384260 & -11.011 & 1384260 & CBN & 1.763145 \\
\hline 416963 & -10.834 & 416963 & ANG, CHD & 1.909153 \\
\hline
\end{tabular}

${ }^{*}$ NCI: National Cancer Institute; CBE/CBN: ChemBridge; PRN: Princeton Biomolecular Research Inc; CHD: ChemDiv; ENM: Enamine.

This model was used for further virtual screening of huge CoCoCo database (8).

Virtual screening of small molecule libraries forms an important component of drug discovery (16). Although the screening results may not meet the highest quality standards, the main objective is to provide novel compounds for further evaluations. Combination of pharmacophore modeling with virtual screening and molecular docking can be used to identify novel RSK2 inhibitors (17).

Database search using the e-pharmacophore model as the three-dimensional query retrieved 500,000 hits from database. All the hits were given as an input for the Virtual Screening Workflow in the Schrödinger suite. 350 ligands were obtained as hits which successfully passed from all the filters explained in the experimental section. Of the 350 hits obtained from virtual screening, 12 hits were selected based on the docking scores and more importantly, based on detailed visual inspection of the interaction of all the hits with the RSK2 active site (Figure 2). LJH685 and all the selected hit compounds, together with their docking scores and vendor names are given in Table 1 .

Amongst all the selected 12 hits, the hit compound 5777208 has the highest docking score and even scored better than the native ligand. It is a symmetrical fused heterocyclic compound containing imidazole ring. Although not all pharmacophore features are matched for 5777208 (Figure 3, top left), it has remarkable interactions with RSK2 active site (Figure 3, top right). The benzene rings in both end of the ligand makes $\pi-\pi$ interactions with Phe 212 of DFG in such a way that the ligand 5777208 acts as if it grabs Phe212. Nitrogen on one of the imidazole ring acts as hydrogen bond acceptor and makes hydrogen bond to the Leu150. Amide nitrogen also acts as hydrogen bond donor and makes the second hydrogen bond with Leu150. The other amide hydrogen makes an extra hydrogen bond with Asp 154 residue of RSK2 active site. Also the size of the ligand is bigger compared to the LJH685 which can make it more selective towards the kinase families containing a compact residue as found in the RSK2. For instance, the kinases RSK3, MSK1-2, PLK1-3, NEK2 and MEKK1 have larger gatekeepers (e.g. methionine, leucine or isoleucine) that restrict large ligands to access to the deep hydrophobic pocket (13). Those overall interactions could be the reason of high docking score and hence, it promises to be potent and also selective RSK2 inhibitor.

Another promising hit compound could be 5919607. It matches all pharmacophore sites 
<smiles>C[NH+]1CCN(c2ccc(-c3ccncc3-c3cc(F)c(O)c(F)c3)cc2)CC1</smiles>

LJH68 (Native Ligand)<smiles></smiles>

5777208

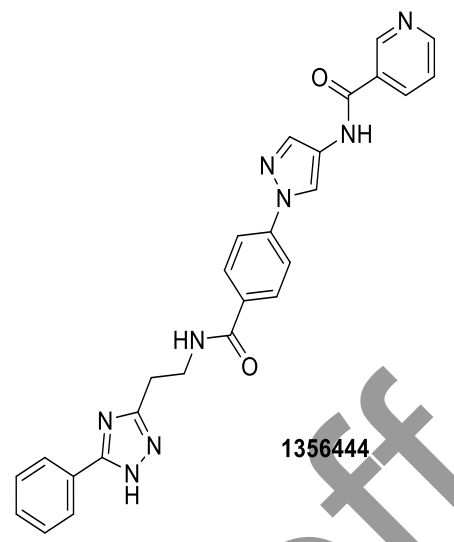<smiles>Cc1n[nH]c(-c2ccc(O)c(O)c2O)c1-c1ccc(Cl)cc1</smiles><smiles>Oc1cccc(/N=C\c2cc(Cc3cccc(O)c3/C=N\c3cccc(O)c3)ccc2O)c1</smiles>

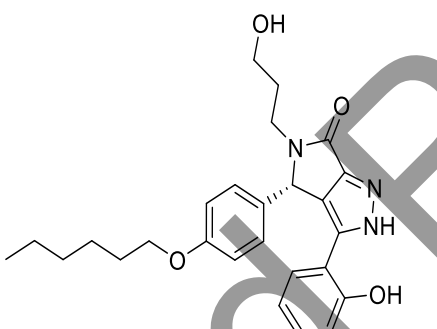

1906060 2231818<smiles>Cc1n[nH]c(-c2ccc(O)cc2O)c1-c1cnn(-c2ccccc2)c1</smiles>

810148

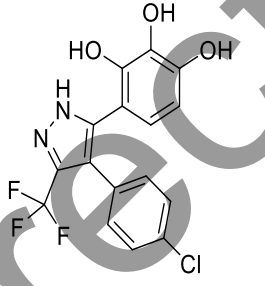

5923852

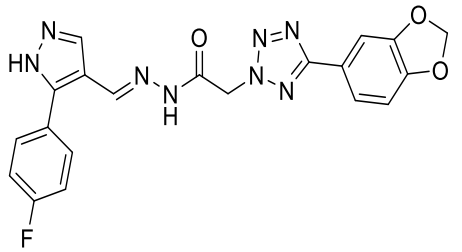

1963198

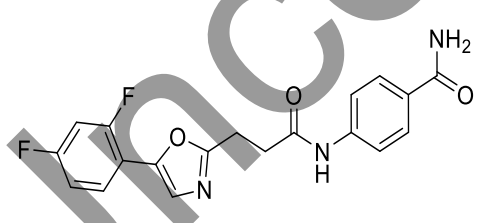

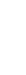

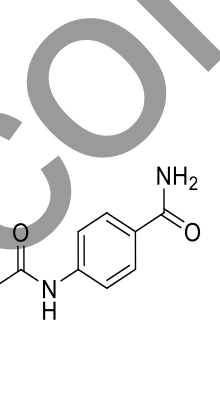

4501898<smiles>COc1ccc(C(=O)N2CCc3n[nH]c(-c4ccc(F)c(F)c4)c3C2)cc1F</smiles>

1384260<smiles>C=CCOc1ccc(C2CC(=O)Nc3n[nH]c(-c4ccc(Cl)cc4)c32)cc1</smiles>

416963

Figure 2. Structure of LJH685 and selected 12 ligands from virtual screening workflow.

of LJH685 (Figure 3, bottom left), yet it's docking score is higher. 5919607 makes an extra hydrogen bond with Leu150 and makes a better interaction with Asp211 of DFG (Figure 3, bottom right). 


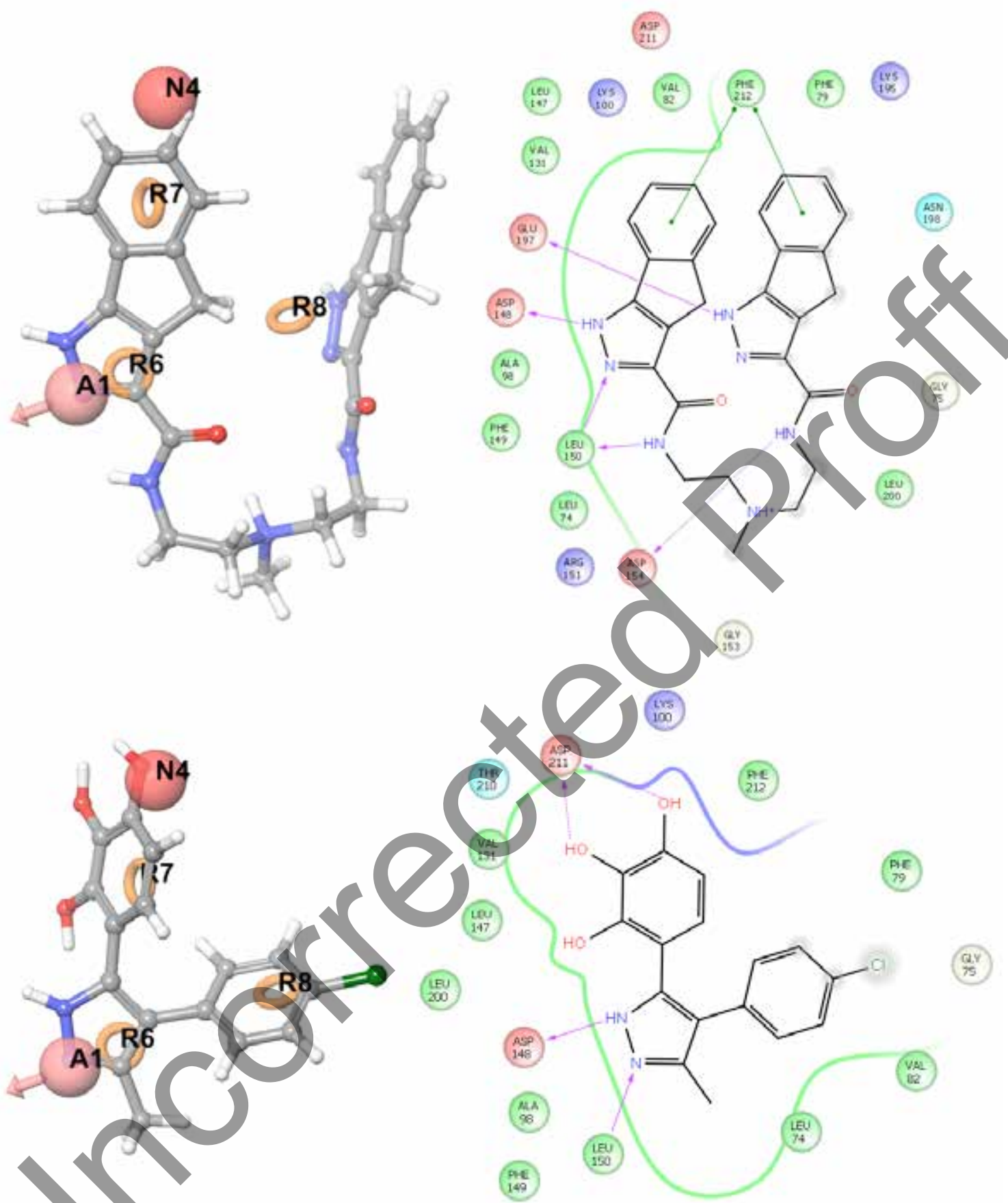

Figure 3. E-Pharmacophore match (left) and binding interactions (right) of the hit compounds 5777208 (top) and 5919607 (bottom). Hydrogen bonds are represented with pink dashed arrows for hydrogen bonds involving amino acid side chain and pink regular arrows for hydrogen bonds involving amino acid backbone. $\pi-\pi$ interactions are shown with green arrows.

\section{CONCLUSION}

An energy optimized structure based epharmacophore model for the RSK family has been generated using the crystal structure of RSK2 in complex with LJH685 which is reported to be one of the most potent and selective RSK inhibitors to date. Virtual screening of large small molecule database using this model and following a series of molecular docking work flows, 350 hits have been obtained. After careful visualization on 
each hit for critical binding modes with the target, 12 hits have been selected. The hit compound 5777208 ranked better than all ligands including the native ligand itself. It has also a large structure which may promise a high selectivity against the kinases that have a compact residue at the gate keeper (e.g. Thr in RSK2). The hit compound 5919607 has also high score compared to the LJH685 and also it matches all pharmacophore sites. The first e-pharmacophore model obtained in this study can be used as a three-dimensional query in searches for RSK inhibitors in additional compound databases. This work may also help in the identification and design of potent and selective novel anti-cancer drugs.

\section{ACKNOWLEDGEMENT}

The support of Rita Podzuna from Schrödinger Inc. is greatly appreciated.

\section{REFERENCES}

1. Manning G, Whyte DB, Martinez R, Hunter T, Sudarsanam $\mathrm{S}$, The protein kinase complemen of the human genome, Science 298, 1912-1934, 2002.

2. Utepbergenov D, Derewenda U, Olekhnovich $\mathrm{N}$, Szukalska G, Banerjee B, Hilinski MK, Lannigan DA, Stukenberg PT, Derewenda ZS, Insights into the inhibition of the p90 ribosomal S6 kinase (RSK) by the flavonol glycoside SL0101 from the $1.5 \AA$ crystal structure of the N-terminal domain of RSK2 with bound inhibitor, Biochemistry 51(33), 6499-6510, 2012.

3. Zhang J, Yang PL, Gray NS, Targeting cancer with small molecule kinase inhibitors, Nat Rev Cancer 9, 28-39, 2009.

4. Fabbro D, Cowan-Jacob SW, Mobitz H, Martiny-Baron G, Targeting cancer with smallmolecular-weight kinase inhibitors, Methods Mol Biol 795, 1-34, 2012.

5. Jain R, Mathur M, Lan J, Costales A, Atallah G, Ramurthy S, Subramanian S, Setti L, Feucht P, Warne B, Doyle L, Basham S, Jefferson AB, Lindvall M, Appleton BA, Shafer CM, Discovery of potent and selective RSK inhibitors as biological probes, J Med Chem 58, 6766-6783, 2015.

6. Derewenda U, Artamonov M, Szukalska G, Utepbergenov D, Olekhnovich N, Parikh HI, Kellogg GE, Somlyo AV, Derewenda ZS, Identification of quercitrin as an inhibitor of the p90 S6 ribosomal kinase (RSK): structure of its complex with the N-terminal domain of RSK2 at $1.8 \AA$ resolution, Acta Crystallogr D 69(2), 266-275, 2013.

7. Aronchik I, Appleton BA, Basham SE, Crawford K, Rosario MD, Doyle LV, Estacio WF, Lan J, Lindvall MK, Luu, CA, Ornelas E, Venetsanakos E, Shafer CM, Jefferson AB, Novel potent and selective inhibitors of p 90 ribosomal S6 kinase reveal the heterogeneity of RSK function in MAPK-driven cancers, Mol Cancer Res 12, 803-812, 2014.

8. Rio AD, Barbosa AJM, Caporuscio $F$ Mangiatordi GF, CoCoCo: a free suite of multiconformational chemical databases for high-throughput virtual screening purposes, Mol Bio Syst 6, 2122, 2010.

9. Maestro, version 10.5, Schrödinger, LLC, New York, NY, 2016

10. Sastry GM, Adzhigirey M, Day $T$, Annabhimoju R, Sherman W, Protein and ligand preparation: parameters, protocols, and influence on virtual screening enrichments, J Comput Aided Mol Des 27, 221-234, 2013.

11. Glide, version 7.0, Schrödinger, LLC, New York, NY, 2016.

12. Phase, version 4.6, Schrödinger, LLC, New York, NY, 2016.

13. Cohen MS, Structural bioinformatics-based design of selective, irreversible kinase inhibitors, Science 308, 1318-1321, 2005.

Bain J, Plater L, Elliott M, Shpiro N, Hastie CJ, Mclauchlan H, Klevernic I, Arthur JSC, Alessi DR Cohen P, The selectivity of protein kinase inhibitors: a further update, Biochem J 408, 297-315, 2007.

15. Kalyaanamoorthy S, Chen, YPP. Energy based pharmacophore mapping of HDAC inhibitors against class I HDAC enzymes. Biochim Biophys Acta (BBA) - Proteins and Proteomics 1834, 317-328, 2013.

16. Marcu MG, Chadli A, Bouhouche I, Catelli M, Neckers LM, The heat shock protein 90 antagonist novobiocin interacts with a previously unrecognized ATP-binding domain in the carboxyl terminus of the chaperone, $\mathrm{J}$ Bio Chem 275, 37181-37186, 2000.

17. Ece A, Sevin F. The discovery of potential cyclin A/CDK2 inhibitors: a combination of 3D QSAR pharmacophore modeling, virtual screening, and molecular docking studies, Med Chem Res 22, 5832-5843, 2013.

Received:03.05.2016

Accepted:26.05.2016 


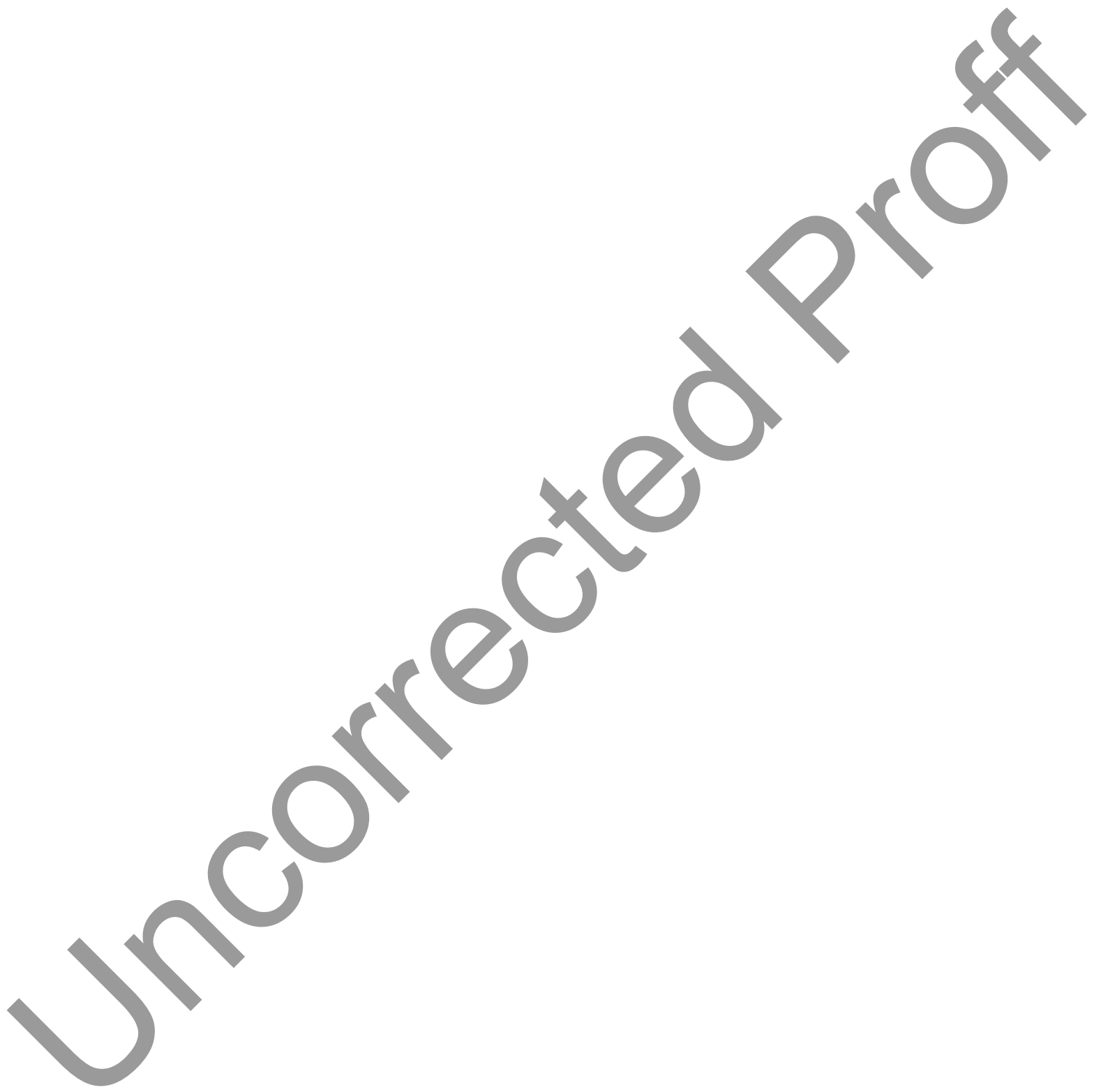

